\title{
Scientific approach \\ to the specific liturgical features in the pontificate of Pope Benedict XVI
}

In the social and Church life of this age questions regarding the head of the Catholic Church, Pope Benedict XVI, and his relationship to the liturgy are often discussed in the media. There is discussion on whether the behavior of the current Pope is seamed liturgical progress or regress. In many countries these questions have been asked by some journalists but even clergymen have varying opinions regarding these questions. Therefore, I chose this topic as the theme of my study, desiring also to write something concerning the great Pope Benedict XVI. Pope Benedict XVI deals with the liturgy personally, celebrating it accurately through his published works which have helped renew the current liturgy.

The development of the liturgy exists in some historical traditions. The history of the development of each liturgical rite is marked by many years of liturgical enculturation and efforts by individuals in the field of liturgy. Liturgy is deeply rooted in the faith of the Church and its theological understanding. Many current journalists have forgotten this fact. The external forms of the liturgy which may have changed over centuries are really something new, more closely related to its fuller experience than in former times. The Pope contributes significantly in this area. He published several works related to the liturgy during his academic years. Let us go to the particularities which occurred during the pontificate of the Pope Benedict XVI. 


\section{Accuracy of the Pope in the following of liturgical precepts}

To start, we must state that Pope Benedict XVI is the right shepherd for observing precepts and the respect of norms in the field of liturgy. This is highly praiseworthy and we must appreciate it in today's world, especially when pluralistic individuals often inaccurately understand such precepts in the field of liturgy while some choose not to follow them at all. Even in our parishes we witness that people are often asking for explanations of some rites or rubrics, allowing for some liturgical acts to be interpreted falsely. Today's world needs clarity in liturgy and we witness this clarity in the pontificate of Pope Benedict XVI. Accurately following rubrics and liturgical precepts is the medicament and condition of the liturgical renewal in current times. ${ }^{1}$ Today we witness that some priests celebrate the liturgy according to their will. It is not the right thing to do. In liturgy there should be unity when it is needed and variability where the precepts of the Church allow for doing so. Unfortunately sometimes we are variable in the opposite way: we are variable where unity is prescribed and we are static, where lovable free style is recommended. The specific feature of the current Pope is the praiseworthy renaissance, renewal of the Latin language in the liturgy as the mother language of the Church and the unifying principle. Several papal documents encouraged this process in the past.

\section{Exhortation Sacramentum caritatis}

On the feast of the Chair of St. Peter (February 22, 2007) Pope Benedict XVI issued the postsynodal apostolic exhortation titled Sacramen-

${ }^{1}$ Even today there are some parishes where parishioners have not been instructed accurately or due to their indifference they have not been educated to follow the precepts of the Church in the field of liturgy. Some of these "feast" parishioners complain and make the life of other priests much more difficult because they wonder why some new things have been introduced by other priests when it had not been done in the past. Liturgy it is the time-proven practice of the Church and each priest is obliged to respect the liturgical precepts regardless of the preference of the people. It is the struggle of some priests who want to truthfully follow the liturgical precepts, recommendations and norms within the spirit of fidelity to the Church. I would like to thank many brothers in priestly ministry because they are the hand of the Church through which the liturgy should be performed authentically under the influence of the Holy Spirit. 
tum caritatis: ${ }^{2}$ On Eucharist - source and climax of the life and mission of the Church. This new exhortation brings many dogmatic as well practical liturgical and pastoral directions for the believers of the Church. It emphasizes that it is necessary to live Eucharist as the mystery of the faith. The liturgy should be celebrated authentically with clear understanding that intellectus fidei has been related to liturgical actions of the Church since the very beginning. We see here that the teaching of Benedict XVI on indivisible unity of the confessed faith, liturgical actions and new spiritual cult is the expansion of the Constitution of the Second Vatican Council Sacrosanctum Concilium which says that "every liturgical celebration, because it is an action of Christ the priest and of His Body which is the Church, is a sacred action surpassing all others; no other action of the Church can equal its efficacy by the same title and to the same degree." ${ }^{3}$ The teaching of Benedict XVI is an example of acceptance of the Council documents in the spirit of hermeneutical continuity. The Pope referred to it as the necessary key for the understanding and acceptance of the Second Vatican council. ${ }^{4}$ Benedict XVI confirmed that difficulties and many violations of liturgical precepts cannot overshadow positive aspects and validity of the Council reform. ${ }^{5}$ The history of Christianity and Christian thought are formed by the God's grace and promise of salvation since the beginning. It is valid not only for extraordinary history of Old and New Testaments but the history

${ }^{2}$ It was published on March 13, 2007. As the title for this exhortation the Pope chose the term which was used by St. Thomas Aquinas for Christ in bread and wine: Sacramentum caritatis - The Sacrament of Love.

${ }^{3}$ Second Vatican Council, Sacrosanctum Concilium, 7.

${ }^{4}$ In this place we can clearly confirm that the document is the continuation of the Council reform in the area of liturgy and it confirms its validity. It was confirmed by the Cardinal Angelo Scola, the patriarch of Venice who has presented this document to journalists. To their question regarding the return of the missal of Pius $\mathrm{V}$ which was used in the liturgy for four centuries until the Second Vatican Council the cardinal replied that the key for the using of this missal stands on the fact that motives of the division in the Church should not be proposed. He explained that it would be a contradiction in terms if the liturgical acts would become the beginning of the division in the Church; cf. J. Dubina, Zamyslenie nad posynodálnou apoštolskou exhortáciou Svätého Otca Benedikta XVI. Sacramentum caritatis, http://www.knazi.sk/liturgia/litvysvetold.php [March 13, 2008].

${ }^{5}$ Cf. J. Dubina, Zamyslenie nad posynodálnou apoštolskou exhortáciou Svätého Otca Benedikta XVI. Sacramentum caritatis, op. cit. 
of humankind in general as well which is filled and directed by God's will. For Christian theologians this is the basis and substantiation of the experiment so that we could understand liturgy from anthropology and theological science. Liturgy is the climax of the celebration of the Church, the right and duty of the faithful to actively participate in the liturgy comes from the baptism which we have accepted. According to the teaching of Thomas Aquinas, the faithful are appointed for the liturgy by the baptismal character. ${ }^{6}$ Christian people are the royal and priestly nation which should take part in Christ's priesthood according to their status. ${ }^{7}$ This participation is fully implemented in the liturgy. Ars celebrandi is the best condition for the real participatio actuosa. ${ }^{8}$

We may conclude that Christian liturgy possesses a uniqueness which distinguishes it from the pagan cults of ancient times and through the celebration of liturgy arises a whole new type of construction of the liturgical community: liturgical gathering is not an assembly as public as in the ancient theatre; in liturgy there is no "viewer," but everyone is a "co-actor."

Even here we can see that the Pope wants to emphasize and clarify some liturgical acts which have been used in the Church but they are performed rather automatically. He emphasizes that the Liturgy of the World should be prepared and experienced appropriately by the speakers and priests. The Pope challenges speakers to be prepared before the reading and he asks that the priests improve the quality of their homilies. The Pope also recommends the Liturgy of Hours for lay persons especially Lauds, Vespers, Compline and celebrations of vigils. Furthermore, we would like to say that the Pope discusses some important questions

${ }^{6}$ „Laici autem participationem liturgicam actuosam praestant, et quidem vi characteris baptismalis" - T. Akvinský, Summa theologica, III, q. 63a, 6.

${ }^{7}$ Cf. J. Lécuyer, Le sacerdoce dans le mystère du Christ, Paris 1957, p. 171-228.

${ }^{8}$ Each liturgical community is the response to God's offer so that God's people would actively communicate with God and among themselves as well. This is the real communication in the liturgy in the participation in divine life and being. The process participationis actuosae between free God and liberated human person has its special conditions and structures: A human person in the liturgy is always endowed by God (God's grace) sooner than he may endow. Therefore the earthly existence of the human persons is decisive for the modality of this exchange which is embodied in the emphasis formed by the liturgy because God is the associate and main actor of the liturgy. He is the main initiator in the liturgical community, Christ is the first liturgic who offers sacrifice to his Father. 
in the document such as the usage of Latin in the liturgical celebrations, education of the faithful for the Gregorian chant and knowledge of some basic Mass prayers in Latin in parishes as well, ${ }^{9}$ enculturation, participation in the liturgy via mass media, possibility of unity of the community with the sick persons who are at home or in hospitals, presence of non-Catholic in the liturgy and so on. In the exhortation Benedict XVI pays attention to the imprisoned, migrants or small communities. ${ }^{10}$ Next he speaks about Church art: Religious iconography must be oriented to sacramental mystagogy (art. 41) and deeper knowledge of forms of sacral art is needed. Liturgical celebrations in small groups should be harmonized with the pastoral offer of the diocese and they must not be in contradiction or as a parallel to the life of the local church. Small groups should serve for unity of the community in the liturgy. In article 69 the exhortation talks about the site of the shrine in the church and the exhortation is concluded by themes such as the Eucharist as the new evangelization, centre of the priestly spirituality and transformation or unity. The goal of the participation in the liturgy (emphasized in the exhortation) is inner unanimity which is expressed outwardly in the unity of gestures, responses and common elements of the liturgical celebration. This participation is not limited by the freedom of the faithful but it is the fruit of the Spirit and fulfilment of the community.

\section{Motu proprio Summorum pontificum}

An important milestone in the field of the liturgy for the Pope is motu proprio Summorum pontificum issued in Rome on July $7^{\text {th }}, 2007$ regarding the celebration of liturgy according to the Missal of the blessed John XXIII. ${ }^{11}$ Despite the fact that this motu proprio is related to liturgy and liturgical affairs, it is not a liturgical but rather legal precept of the Ro-

\footnotetext{
${ }^{9}$ Sometimes parishioners ask for the Mass with Latin parts because they view transmission of Holy Mass from Rome for example and they can actively answer.

${ }^{10} \mathrm{~J}$. Dubina, Zamyslenie nad posynodálnou apoštolskou exhortáciou Svätého Otca Benedikta XVI. Sacramentum caritatis, http://www.knazi.sk/liturgia/litvysvetold.php March 13th, 2008.

${ }^{11}$ This motu proprio came into force in the Fests of the Exultation of the Holy Cross on September 14, 2007.
} 
man high priest..$^{12}$ Let us notice some important aspects of this motu proprio. "The best way for appropriate understanding of the importance of the new document is by reading of the papal letter which accompanies the document," said the spokesperson of the Holy See Federico Lombardi. The accompanying letter ${ }^{13}$ was addressed by Benedict XVI to the bishops of the whole world in order to clarify his motives and remove unsubstantiated fears from the Latin liturgy. He emphasizes that his document is "the fruit of much reflection, numerous consultations and prayer." He does not conceal that there have been very divergent reactions ranging from joyful acceptance to harsh opposition, about a plan whose contents were in reality unknown. Before clarifying his intention the Pope decided to remove two main fears which he considers unfounded. In the first place, there is the fear that the document detracts from the authority of the Second Vatican Council and in the second place, the fear was expressed in discussions about the awaited motu proprio, that the possibility of a wider use of the 1962 Missal of blessed John XXIII would lead to disarray or even divisions within parish communities. ${ }^{14}$ The possibility of celebrations of Holy Masses according to so called Tridentine rite was given by the letter Quattuor abhinc annos from 1984. It was published before issuing of this motu proprio. This document is the legal directive of the Congregation for divine cult and discipline

${ }^{12}$ Cf.J. Duda, Komentár kmotu proprio Summorum pontificum, “Tribunál” 2 (2007), op. cit.

${ }^{13}$ Motu proprio was written in Latin, the accompanying letter was written in Italian.

${ }^{14}$ The theme of the Latin rite in the Catholic Church was discussed by the Cardinal Castrillon Hoyos at the conference in Aparecide in May 2007. He is the chairperson of the Vatican commission Ecclesia Dei which takes care of the Traditionalist faithful. He explained the Catholic Church does not concentrate on known schismatic situations and "it wants to maintain the previous Latin liturgy alive in the celebration of the Eucharist as well as administration of the sacraments." The commission should become an independent organ of the Holy See with its own specific goal focused on maintaining the value of the traditional Latin liturgy. He emphasized that it is not the return to the past or negation of the reform from 1970 but "it is the grandanimous offer of the Pope who wants to make all the treasures of the Latin liturgy available. These treasures nourished the spiritual life of many generations and Catholic faithful for many centuries." Cardinal Hoyos mentioned the "intention" of the Holy Father to "extend the possibility of celebration of Holy Mass and sacraments for the whole Latin church according to liturgical books issued by the blessed John XXIII in 1962." He stated: "Holy Father is interested in this liturgy which was never abolished and he thinks that now it is the time to facilitate the access to this liturgy and establish it as the extraordinary form of one Roman rite." 
of sacraments which was addressed to all the chairpersons of national bishop's conferences of the whole world..$^{15}$ In 1988 John Paul II by his apostolic letter motu proprio Ecclesia Dei encouraged bishops to use widely this indult for the wellbeing of all the faithful who request it.

What new does the new motu proprio Summorum pontificum bring? The main new thing is the permission to celebrate Mass according to the Roman Missal issued by the blessed Pope John XXIII in 1962 which was never totally abolished. This Mass is an extraordinary form of liturgy. ${ }^{16}$ Missal issued by Paul VI is the ordinary form of the celebration of the Eucharist. ${ }^{17}$ Therefore it is not correct to talk about "two rites" because the Pope emphasizes that it is a dual form of one and the same rite..$^{18}$ For Masse celebrated without people in any day except for Paschal Triduum any Catholic priest of the Latin rite (diocesan or religious) may use either Roman Missal of the blessed Pope John XXIII issued in 1962 or the Roman Missal declared by the High Priest Paul VI in 1970. A priest does

${ }^{15}$ The Pope desiring to help these groups offered diocesan bishops the possibility to use the indult which allows the priests and the faithful who are mentioned in the submitted request to celebrate Holy Mass using Roman Missal from 1962 under the following conditions:

- Priests and the faithful who are interested in this indult must publicly and clearly declare that they do not doubt legitimacy and accuracy of the teaching of the Roman Missal declared by the Pope Paul VI;

- Tridentine Massed may be celebrated only for groups of the faithful who request it;

- Mass in the Tridentine rite may be celebrated only in a church or chapel determined by the bishop (it cannot be a parish church, exception is possible in extraordinary cases), a bishop determines the day and conditions of the celebration;

- Mass may be celebration only in Latin according to 1962 Missal;

- It is forbidden to combine texts from various Missals;

- A bishop must inform the Congregation for divine cult and discipline of sacraments about priests and the faithful who were given indult for the celebration of the Mass in Tridentine rite.

The letter is found in "Acta apostolicae sedis" 76 (1984), p. 1088-1089; P. Caban, Medzi Tridentom a Druhým Vatikánom, "Impulz" 3 (2007) nr 1, p. 130-131.

${ }^{16} \mathrm{Cf}$. Benedict XVI, Summorum pontificum, 1.

${ }^{17}$ The1962 Missal differed from the current Missal of Paul VI because there is a Missal and lectionary in one book, it has only one Eucharistic prayer (so called Roman canon corresponding to the current First Eucharistic prayer), and a part of the canon and various prayers are recited by the priest silently. The Missal of blessed John XXIII does not presuppose concelebrated Masse and it uses a different liturgical calendar.

${ }^{18} \mathrm{Cf}$. Benedict XVI, Summorum pontificum, 1. 
not need any special permission of the Apostolic See or his bishop for such celebration according to one or the other Missal. ${ }^{19}$

Benedict XVI was gnerous to the faithful who prefer Tridentine liturgy. ${ }^{20}$ He permitted them to celebrate Holy Mass according to the

${ }^{19} \mathrm{Cf}$. ibidem, 2, 3: Regarding the religious persons: "Communities of Institutes of consecrated life and of Societies of apostolic life, of either pontifical or diocesan right, wishing to celebrate Mass in accordance with the edition of the Roman Missal promulgated in 1962, for conventual or 'community' celebration in their oratories, may do so. If an individual community or an entire Institute or Society wishes to undertake such celebrations often, habitually or permanently, the decision must be taken by the Superiors Major, in accordance with the law and following their own specific decrees and statutes."

${ }^{20}$ For example on the internet there were some appeals from so called Circle of Leo XIII for the faithful to send requests for celebration of the Masses according to blessed John XXIII to their bishops. I will cite the text in full according to the website: "Request for the archbishop to provide celebration of the Trident liturgy. Your Excellence, Mons. Jan Sokol, archbishop of Bratislava-Trnava, Laudetur Iesus Christus! The most reverend father archbishop, dear father! We, members of the Slovak circle of Leo XIII - faithful sons of one, true, holy, Catholic and apostolic Church with our brothers and sisters appeal to you with the humble request to allow access - from your kind bishop's grace - to the most Holy Christ's sacrifice, Holy Mass, in the traditional rite of the Holy Church according to Ordo Missae dated in 1962, promulgated by blessed John XXIII, in harmony with Motu proprio of the Holy Father, the Pope Benedict XVI dated July $7^{\text {th }}, 2007$. We submit our request because we realize beauty, power and sanctity of Latin, the language of Christian centuries, angelic language with inexpressible value (cf. Holy Father Paul VI in the address during general audience on November $26^{\text {th }}, 1969$ ) and in harmony with the apostolic letter motu proprio Ecclesia Dei of the Holy Father, late John Paul II from 1988 where the Highest priest encourage pastors of the Church to be grandanimous toward sheep inclined to ancient Latin liturgical tradition in which they want to deeply experience the most noble sacrifice and adore really and substantially present Christ in the Sacrament (cf. John Paul II, Ecclesia Dei, 7. c). Similarly we appeal to you according to the accompanying letter to Motu proprio Summorum pontificum of the current Pope, Holy Farther Benedict XVI. According to him celebration of the "Tridentine" liturgy "will bring goodness to all if the richness will be preserved and this richness grew in faith and prayer of the Church and if it is given the appropriate place." (cf. Benedict XVI). Holy Mass is the central point of our lives and we consider it the true and appropriate sacrifice to God - therefore we desire to adore God in Holy Mass vested in the habit of the mystery of the language of general Church according to words of the Constitution of the Second Vatican Council Sacrosanctum Concilium - On sacred liturgy: “... in faithful obedience to tradition, the sacred Council declares that the Holy Mother Church holds all lawfully acknowledged rites to be of equal right and dignity; that she wishes to preserve them in the future and to foster them in every way." (cf. Second Vatican Council, Sacrosanctum concilium, 4). We hope, dear farther, that you will fulfill our request. We thank you in advance for your bishop's kindness and we remain 
1962 Missal without any difficulties, ${ }^{21}$ they may receive the sacraments of baptism, matrimony, repentance and the anointment of the sick as well as a confirmation according to pre-Council liturgical precepts ${ }^{22}$ and clergy may use prayers of pre-Council breviary. ${ }^{23} \mathrm{He}$ entrusted judgment of the pastoral situation for the appropriateness of use of preCouncil rite to parish priests. ${ }^{24} \mathrm{~A}$ parish priest will solve any difficulties with his diocesan bishop who may consult the commission Ecclesia Dei. Benedict XVI in his motu proprio allowed freedom in the celebration of the liturgy according to pre-Council liturgical books. Diocesan bishops and parish priests have the task to be prepared to fulfill the requests of the faithful regarding the liturgy according to Missal of the blessed John XXIII. Some of them will have to learn the ancient pre-Council liturgy according to ancient liturgical precepts..$^{25}$

Motu proprio is accompanied by the papal Letter to bishops where the Pope clarifies the motu proprio and mentions possibilities how to implement Tridentine liturgy in practice. ${ }^{26} \mathrm{He}$ speaks that not only did older generations like the ancient Latin liturgy but in the meantime it had clearly been demonstrated that the youth too had discovered this liturgical form, felt its attraction and found in it a connection with the Mystery of the most Holy Eucharist was particularly suited to them. The Pope writes that there is no need to fear and the missal should unite the faithful and not to seperate them. The celebration of Mass according to Missal of blessed John XXIII is the ministry to minor groups of the faith-

in respect, love, commitment and prayers for you and the whole Holy Church. OMNES AD MAIOREM DEI GLORIAM! Members of the Circle committed to you in Christ." http:// www.sacrumimperium.sk/node/97 [March 7, 2008].

${ }^{21} \mathrm{Cf}$. Benedict XVI, Summorum pontificum, 2.

${ }^{22} \mathrm{Cf}$. ibidem, 9, 1-2.

${ }^{23} \mathrm{Cf}$. ibidem, 9, 3.

${ }^{24} \mathrm{Cf}$. ibidem, 9, 1.

${ }^{25}$ Cf. J. Duda, Komentár k motu proprio Summorum pontificum, "Tribunál" 2 (2007), http://tribunal.kapitula.sk/2007-2/komentar.htm [March 14, 2008].

${ }^{26}$ In the letter accompanying motu proprio the Pope mentioned serious deformation of the liturgy which occurred in the past: "In many places celebrations were not faithful to the prescriptions of the new Missal, but the latter actually was understood as authorizing or even requiring creativity, which frequently led to deformations of the liturgy which were hard to bear." Benedict XVI, Letter of His Holiness Benedict to the bishops on the occasion of the publication of the apostolic letter "Motu proprio data" Summorum Pontificum, Trnava 2007, p. 24-25. 
ful which results from the real situation where the communities of the faithful are living: the use of the old Missal presupposes some liturgical formation and knowledge of Latin language as Benedict XVI emphasizes. According to Benedict XVI the relationship to the liturgy is more important than various fears. According to the Pope the relationship to the liturgy is developed and has progressed in history but has never been broken. The Pope wrote: "What earlier generations held as sacred, remains sacred and great for us too, and it cannot be all of a sudden entirely forbidden or even considered harmful." Both form of the Roman rite may enrich each other. New saint persons and some new prefaces must be inserted into the old Missal so this Missal should be developed..$^{27}$ As Vatican radio informed motu proprio means that priests may use the 1962 Missal of blessed John XXIII without any special permit in Masses without people and the faithful who request it may participate in such liturgies. In parishes where there is a constant group of the faithful interested in such liturgy priests should fulfill their request. In Holy Masses celebrated with the participation of the people readings should be read in local language and it is recommended for the people to recite some parts of the Holy Mass alongside with the priest such as Kyrie, Gloria, Credo, Sanctus, Agnus Dei, and a priest should not recite the whole Mass silently. It is possible to administer the sacraments of matrimony, baptism, repentance, anointing of the sick and confirmation according to the Tridentine rite. The clergy may pray the breviary issued by John XXIII in 1962. Bishops may establish so called personal parishes or they may even anoint chaplains for the faithful who are interested in the old liturgy. However, a group of lay persons interested in the liturgy according to the Missal of the Pope John XXIII should ask the local priest first. If he refuses, they should then ask the bishop and if he does not provide such celebration, they should ask the papal commission Ecclesia Dei. This commission was established by John Paul II in 1988 to control the fulfillment of the precepts of this motu proprio. Bishops are asked by the Holy Father to write about their experiences with new precept to the Holy See after 3 years so it would be possible to find solutions of some difficulties. ${ }^{28}$

\footnotetext{
${ }^{27} \mathrm{Cf}$. http://www.vaticanradio.org/slo/Articolo.asp?c=144010 [March 12, 2008]. ${ }^{28} \mathrm{Cf}$. ibidem.
} 
$*$

There is nothing to reproach the current Pope in the field of innovation of liturgy but we must state that the Pope is consistent and conscientious in observing of liturgical precepts. It should be so and the Pope is the example for the world. Let us not expect that the liturgy is going through some revolutions. It is a living organism just like the Church. It is the living mystical body of Christ which is living in flow of history and encounters many cultures where it lives. We may be thankful for such progressive attitudes of the current Pope Benedict XVI because they unify the liturgy and emphasize accuracy and fidelity to the precepts of the Church which are much needed today.

Bratislava

PETER CABAN

\section{Keywords}

Benedict XVI, Tridentine rite, Latin rite, renewal of liturgy, Latin language, Missal of Pope John XXIII

\section{Streszczenie}

Naukowe spojrzenie na wybrane zagadnienia

liturgiczne w pontyfikacie papieża Benedykta XVI

Artykuł dotyczy pontyfikatu papieża Benedykta XVI i jego wkładu w dziedzinie liturgii. Zwraca uwagę na różne fakty rozwijające się w duchu autentyczności i wierności względem liturgii rzymskokatolickiej, na możliwości liturgicznej formy rytów, na nowe motu proprio i na użycie języka łacińskiego w liturgii zachodniej. Artykuł pragnie dać obraz pontyfikatu obecnego papieża w relacji do duszpasterskiej posługi w parafiach. Chce ukazać, że liturgia w jej różnorodności nie jest nigdy krokiem wstecz, ale przejawem autentyczności i wierności względem orędzia Chrystusa.

\section{Słowa kluczowe}

Benedykt XVI, ryt trydencki, ryt łaciński, odnowa liturgii, język łaciński, mszał Jana XXIII 
